Plasma concentration and urinary excretion of calcium and phosphate before and after treatment with atenolol. (Normal values given in parentheses)

\begin{tabular}{|c|c|c|c|c|}
\hline & \multicolumn{2}{|c|}{ Plasma concentration } & \multicolumn{2}{|c|}{24 Hour urinary excretion } \\
\hline & $\begin{array}{l}\text { Corrected calcium } \\
(\mathrm{mmol} / \mathrm{l})\end{array}$ & $\begin{array}{l}\text { Phosphate } \\
(\mathrm{mmol} / \mathrm{l})\end{array}$ & $\underset{(\mathrm{mmol} / 24 \mathrm{~h})}{\text { Calcium }}$ & $\begin{array}{l}\text { Phosphate } \\
(\mathrm{mmol} / 24 \mathrm{~h})\end{array}$ \\
\hline Normal range & $2 \cdot 12-2 \cdot 62$ & $0 \cdot 8-1 \cdot 45$ & $2 \cdot 5-7 \cdot 5$ & $15-40$ \\
\hline \multicolumn{5}{|c|}{ Case I } \\
\hline $\begin{array}{l}\text { Before treatment } \\
\text { After treatment for one week with atenolol } 100 \mathrm{mg}\end{array}$ & $\begin{array}{l}2 \cdot 77 \\
2 \cdot 65\end{array}$ & $\begin{array}{l}0.67 \\
0.95\end{array}$ & $\begin{array}{l}16 \cdot 2 \\
11 \cdot 2\end{array}$ & $\begin{array}{l}29 \cdot 9 \\
22 \cdot 6\end{array}$ \\
\hline \multicolumn{5}{|c|}{ Case 2} \\
\hline $\begin{array}{l}\text { Before treatment } \\
\text { After } 10 \text { days' treatment with atenolol } 100 \mathrm{mg} \\
\text { Seven days after stopping atenolol }\end{array}$ & $\begin{array}{l}2 \cdot 43 \\
2 \cdot 27 \\
2 \cdot 37\end{array}$ & $\begin{array}{l}1 \cdot 12 \\
1 \cdot 45 \\
1 \cdot 12\end{array}$ & $\begin{array}{r}12 \cdot 5 \\
8 \cdot 6 \\
17 \cdot 4\end{array}$ & $\begin{array}{l}27 \cdot 9 \\
35 \cdot 9 \\
42 \cdot 5\end{array}$ \\
\hline
\end{tabular}

3 Meyrier A, Valeyre D, Bouillon R, Psillard F, Battesti J-P, Georges R. Resorptive versus absorptive hypercalciuria in sarcoidosis: correlations with 25-hydroxy vitamin D3 and 1-25-dihydroxyvitamin D3 and parameters of disease activity. Of Med 1985;54:269-81.

4 Kukreja S, Henderson W, Hargis G, Fisherman E, Bowser N, Williams G. Role of adrenergic stimuli in parathyroid hormone secretion in man. 7 Clin Endocrinol Metab 1975;40:478-81.

5 Caro J, Besarab A. Propranolol therapy for hyperparathyroidism? Lancet 1978;i:827.

(Accepted 13 February 1987)

Wycombe General Hospital, High Wycombe, Buckinghamshire C J BUSHE, MB, BS, medical registrar

\section{Successful cadaveric renal transplantation from a donor who died of cyanide poisoning}

Most kidneys used for cadaveric renal transplantation come from victims of fatal head injuries or cerebrovascular accidents. Patients who suffer other causes of irreversible brain death should also be considered as potential donors, even though they may at first appear unsuitable. We report a successful renal transplantation from a young man who died of cyanide poisoning.

\section{Case report}

A 24 year old man was cleaning a vat containing silver cyanide when he was overcome by fumes and collapsed into several inches of slurry. On arrival in the casualty department 15 minutes later he was unresponsive, apnoeic, and hypotensive. His skin was brick red, which is compatible with cyanide toxicity. After resuscitation $300 \mathrm{mg}$ of dicobalt edetate was given at one, two, three, and seven minutes. Spontaneous respiration resumed, although he remained haemodynamically unstable. Twenty four hours after admission urine output and blood pressure were satisfactory. Electroencephalograms obtained at this time and 48 hours after admission showed no cerebral activity. As he remained haemodynamically stable and blood cyanide values were rapidly falling to nontoxic concentrations (table) the possibility of organ donation was considered. The criteria for brain death were satisfied four days after admission, and shortly afterwards donor nephrectomy was undertaken. Serum urea and creatinine concentrations were $10.7 \mathrm{mmol} / 1$ and $146 \mu \mathrm{mol} / 1$ respectively on the day the kidneys were removed. Urine output during the 24 hours before the operation was $2883 \mathrm{ml}$.

The recipients were a suitably matched 43 year old man and 52 year old woman. Both kidneys were perfused immediately after removal with ice cold Marshall's solution and transplanted within 24 hours. Renal transplant biopsy samples taken

\section{Blood cyanide concentrations}

\begin{tabular}{|c|c|c|c|c|c|c|c|}
\hline & \multicolumn{3}{|c|}{ Day of admission } & \multicolumn{3}{|c|}{ Day 1} & \multirow{2}{*}{$\frac{\text { Day } 2}{0900}$} \\
\hline Time: & 1600 & 1800 & 1900 & 0400 & 0900 & 1400 & \\
\hline Blood cyanide $(\mu \mathrm{mol} / \mathrm{l})$ & 804 & 819 & 607 & 23 & 15 & 15 & 8 \\
\hline
\end{tabular}

30 minutes after transplantation showed acute moderate tubular damage only. Cyclosporin A ( $5 \mathrm{mg} / \mathrm{kg}$ daily intravenously for 48 hours followed by $15 \mathrm{mg} / \mathrm{kg}$ daily by mouth) and prednisolone ( $20 \mathrm{mg}$ daily) were used as immunosuppressive agents. Neither kidney underwent a primary diuresis, necessitating maintenance dialysis for 11 days. Renal transplant biopsy samples taken on the ninth postoperative day showed acute mild to moderate tubular damage. Mild cellular rejection in one of the kidneys was treated with $200 \mathrm{mg}$ of oral prednisolone for three days. Twenty one days after transplantation creatinine clearances were $33.4 \mathrm{ml} / \mathrm{min}$ and $36.7 \mathrm{ml} / \mathrm{min}$. Six months after transplantation the recipients remained well; urea and creatinine concentrations were $9.7 \mathrm{mmol} / 1$ and 243 $\mu \mathrm{mol} / \mathrm{l}$ and $20.9 \mathrm{mmol} / \mathrm{l}$ and $167 \mu \mathrm{mol} / \mathrm{l}$, respectively.

\section{Comment}

We believe that this is the first report of successful organ transplantation from a donor dying of cyanide poisoning. Cyanides are rapidly absorbed by all tissues, particularly the lungs. ${ }^{1}$ The cyanide ion combines intracellularly with the ferric ion in cytochrome oxidase, forming an inactive complex which blocks the electron transport system and cellular utilisation of oxygen. In sufficient dosage death is caused by respiratory failure because the nerve cells of the respiratory centre are particularly vulnerable to lack of oxygen. Blood cyanide concentrations of $8 \mu \mathrm{mol} / \mathrm{l}$ indicate substantial intoxication and a value of more than $38 \mu \mathrm{mol} / \mathrm{l}$ is usually fatal. ${ }^{2}$

It has been suggested that if cardiac output and respiration can be maintained, up to half of the cyanide in the circulation can be metabolised within one hour of exposure. ${ }^{3}$ Eighty per cent of cyanide is detoxified by the liver enzyme rhodanase to non-toxic thiocyanate, which is excreted in the urine ${ }^{4}$ The high concentration of cyanide recorded during the first three hours in this case probably indicate continuing enteric or percutaneous absorption. Despite these values the patient's kidneys were successfully used for transplantation. This suggests that although victims of fatal cyanide poisoning suffer irreversible brain injury as a result of depression of the respiratory centre, other organs are only reversibly damaged and may be considered for transplantation. Careful evaluation of every patient dying of irreversible brain injury should increase the number of potential donors.

We thank Dr M G Fitzgerald for permission to report details of the donor and the Regional Toxicology Laboratory, Dudley Road Hospital, Birmingham B18, for performing the blood cyanide assays.

1 Arena JM. Poisoning. Toxicology-symptoms-treatments. 3rd ed. Springfield, Illinois: Thomas, 1974:136.

2. Rumack BH, Lovejoy FHjr. In: Doull J, Klassen CD, Amdur MO, eds. Casarett and Doull's toxicology-the basic science of poisons. 3rd ed. New York: Macmillan, 1986:888.

3 Weber D, Frieldberg KD, Lendle L. Evaluation of therapeutic measures in hydrocyanic acid poisoning under the influence of constant cyanide infusion. Naunyn Schmiedebergs Arch Exp Pathol Pharmacol 1962;244:1-16.

4 Finkel AJ, ed. Hamilton and Hardy's industrial toxicology. Bristol: John Wright, 1983:172.

(Accepted 23 March 1987)

Department of Surgery, Queen Elizabeth Hospital, Queen Elizabeth Medical Centre, Birmingham B15 2TH

$P$ W G BROWN, MB, CHB, senior house officer

J A C BUCKELS, MD, FRCS, senior registrar, transplant unit

A B JAIN, FRCS, registrar, transplant unit

P MCMASTER, CHM, FRCS, consultant surgeon, transplant unit

Correspondence to: Mr Buckels. 